\title{
Study on setting up a beekeeping farm and on valorisation of the products obtained - sustainable business in the rural area of Gorj County
}

\author{
Emil-Cătălin Șchiopu ${ }^{1}$, Roxana-Gabriela Popa ${ }^{1}$, and Irina-Ramona Pecingină ${ }^{1}$ \\ ${ }^{1}$ Faculty of Engineering, Constantin Brâncuși University of Tg Jiu, Gorj, Romania \\ E-mail: roxanna_popa@yahoo.com
}

\begin{abstract}
The beekeeping farm is a farm for breeding bees carried out in order to obtain apiculture products (honey, pollen, propolis, wax, royal jelly and bee venom). The bee harvesting is regulated in Romania by the Law on beekeeping No. 383/2013 and it is a technological link of the beekeeping production activity, in which the beekeeper transports and temporarily places the bee families, at the areas suitable for honey production in agricultural or forestry fund. To exploit the productive potential of the bee families, specific work is needed to ensure their optimal development during the main harvest period. The paper presents a study on setting up a beekeeping or apiary farm in a rural area in the Gorj County as a business idea that contributes to rural development and to diversification of the entrepreneur's income. The investment expenses are of 154.200 lei and the net income in the first year of production is of 92.250 lei, so that under favourable weather conditions to achieve 4 harvests per year, the depreciation of the investment costs and getting profit is made from the second year of production.

Keywords: bees, beekeeping farm, products, business, depreciation, profit
\end{abstract}

\section{Introduction}

The bees are of the species Apis mellifera, order Himenoptera. They live together in colonies of 30.000 to 50.000 individuals.

The queen is the mother of the entire bee family, being the only component of the bee family, reproductive fitted. The drone bees represent the males of the bee family and play a single role in the beehive, to mate with the queen.

The working bees hatch from the fecunded queen's eggs, being the most numerous in the beehive, their number varies depending on the season and on the intensity of the harvest (between 15.000 and 60.000). In the beehives, they have important roles in caring of juveniles, harvesting nectar and pollen, constructing the beehives and defending them (Figure 1).

The bee's diseases are American foulbrood, European foulbrood, honey varos, and their pests are: the bee louse, the beeswax moth, the wasp, the bee's wolf, the robin, the mouse.

The apiculture products are:

Honey is obtained from nectar, manna or sweet juices from the different parts of plants and trees, mixed with substances from the salivary glands of bees; in order to obtain honey, which they deposit in the honeycomb cells, bees have a vegetable source (represented by the flower nectar) and an animal source (represented by sweet substances, rich in sugars, removed by some plant parasites, called manna). The nectar is the most important source of quantity and the most qualitative valued. The manna is a sweet, clear and viscous substance, solidified, which during certain periods of the year lies on the 
leaves, branches or stems of the plants, being of vegetal origin (directly secreted by leaves, buds or other parts of the plant) or of animal origin (produced by certain insects). Honey production is a complex process, consisting of the collection of sweet juices by the buccal apparatus and the lid process of the cells in which it is being stored.

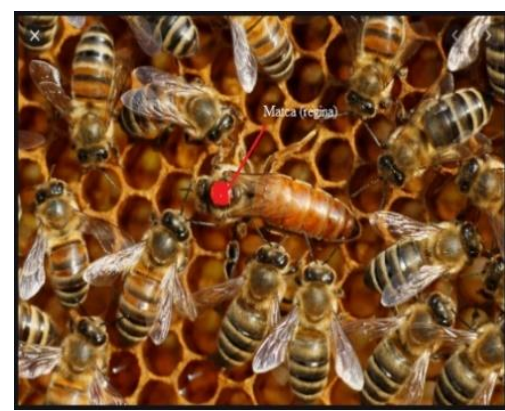

Bee queen

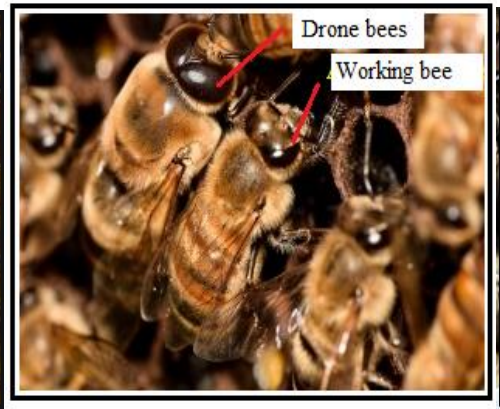

Drone bees

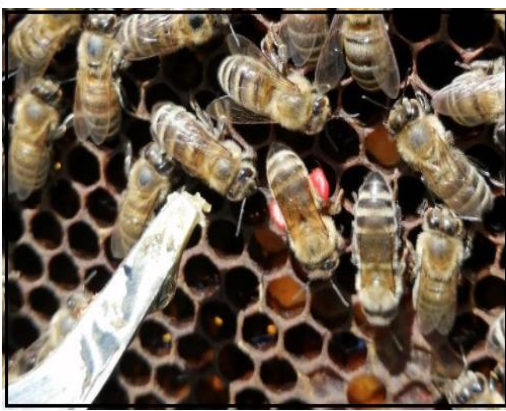

Working bee

Figure 1. The beehives' family

The wax is secreted by the cerigenic glands of 13-18-day-old working bees. When secreted, the wax is liquid and in contact with air solidifies as small scales, which after a certain time becomes yellow. Depending on the way of harvesting it from the beehive, beeswax is classified into: beehive wax, press wax and extractive wax.

The pollen ensures the maturity of young bees and the strengthening of their body for winter, and is also used in human nutrition due to its therapeutic qualities. The whole body of the bee is harvested through the tiny hairs of the head, thorax, abdomen, buccal parts and their three pairs of legs.

The royal jelly is a protein product, secreted by pharyngeal and mandible glands of working bees and is used by the beehive to feed the bees and queen larvae during the first 3 days of their life and the adult queen throughout its entire life.

The bee venom is a mixture of secretions of the venom glands of bees and serves together with the needle for defence. It is stored in the venom bag and removed to outside at the time of stinging.

The propolis or the glue of the bees is a natural product, which is harvested by bees from some plants' blossoms resin, to which bees also add their own secretions. It is used to adhere cracks smaller than 3-5 $\mathrm{mm}$ from the beehive, to level irregularities inside the beehives, to stick the panels and to attach the frames to each other.

The beehive is the construction that shelters and protects the bee family from weather and pests and can be vertical, with shed or horizontal and meets the following conditions:

- large capacity (70-90 1, to allow the development of large families)

- moving parts (that fit any beehive, belonging to the same model)

- properly constructed, simple, of dry material, spruce wood

- practical methods of securing component parts during transportation

- opening cover through the top of it.

The vertical beehive with shed consists of: base, body, crop shed, ceiling, lid, diaphragm, frames and entrance block (Figure 2). The horizontal beehive consists of base, body, crop shed, ceiling, cover, diaphragms, frames, holding-down device during transport, entrance block and feeder (Figure 3). 


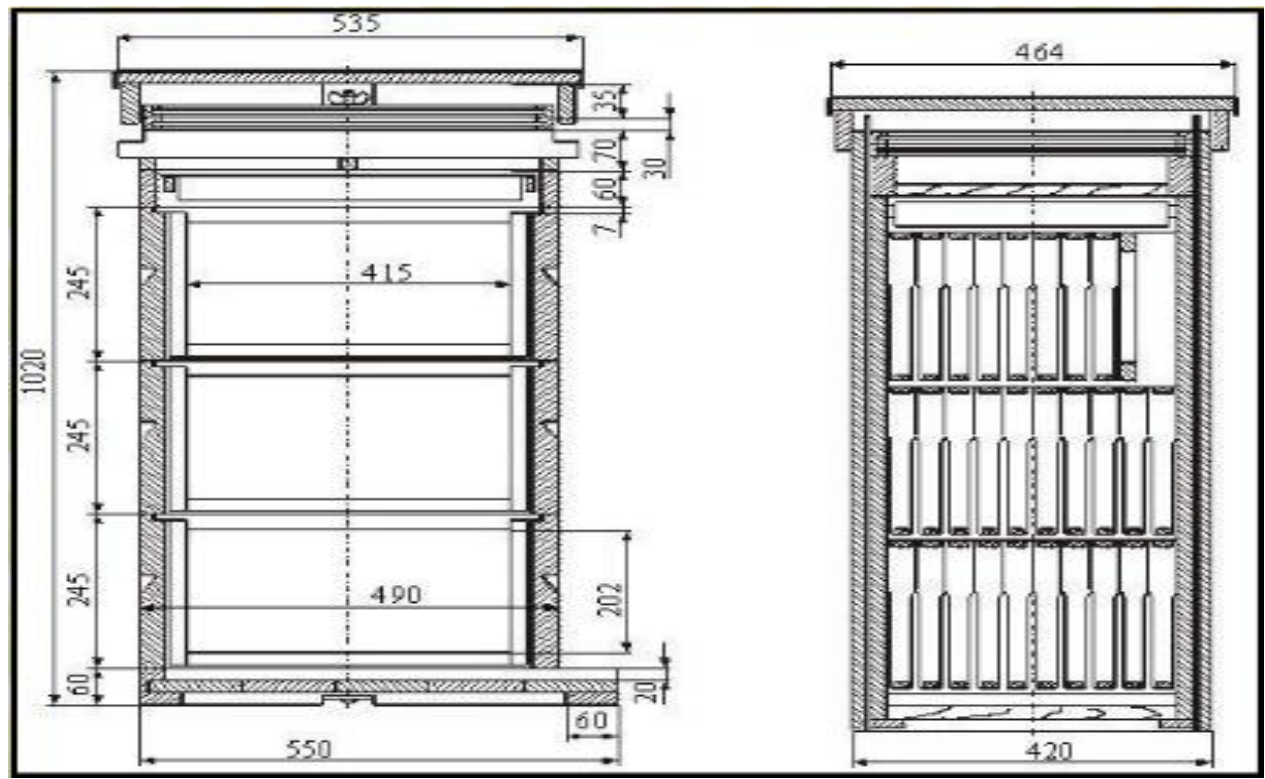

Figure 2. Vertical beehive with shed (section view)

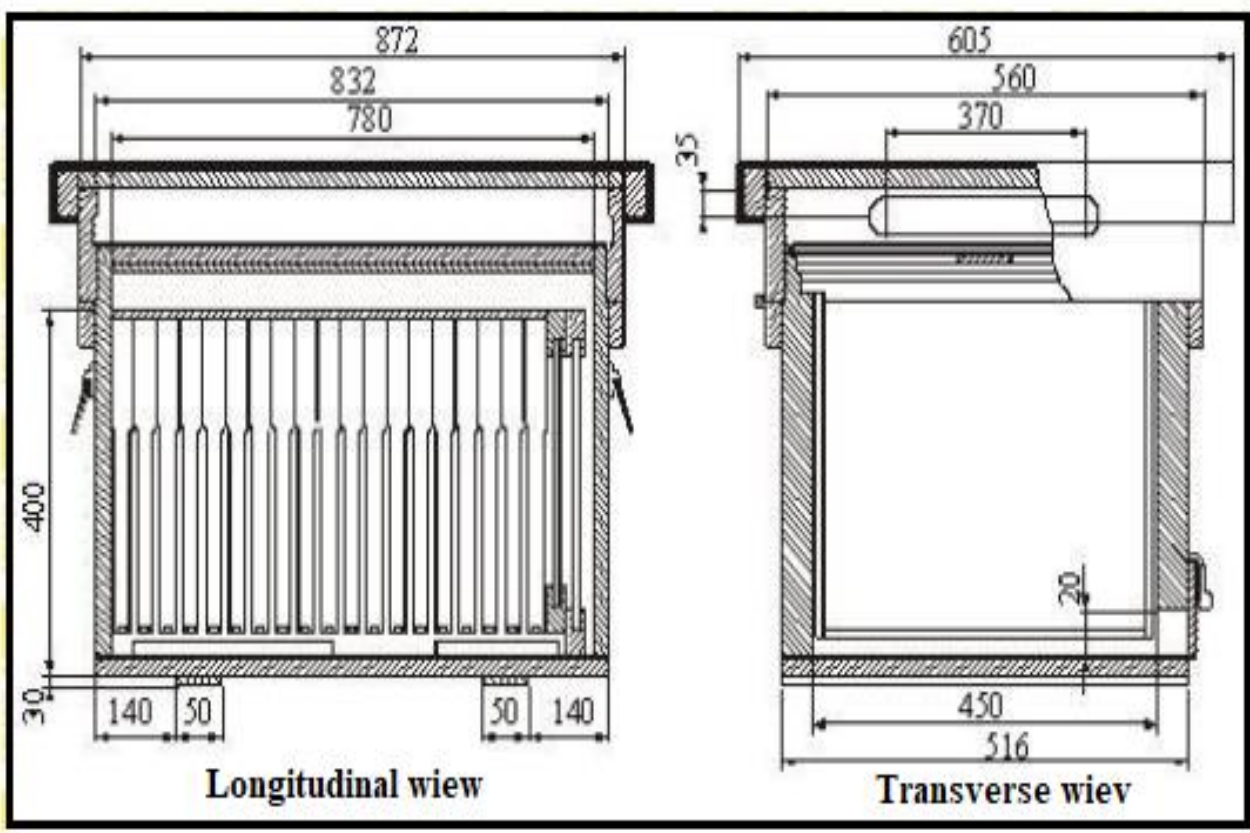

Figure 3. Horizontal beehive (longitudinal and transverse view)

\section{Material and method}

For the establishment of a beekeeping or apiary farm in the rural area of Gorj county, a survey was carried out on a property land, arable use category, with an area of $2000 \mathrm{~m}^{2}(20 \mathrm{~m}$ wide and $100 \mathrm{~m}$ long) in the village of Jupanesti, at a distance of $40 \mathrm{~km}$ from Targu Jiu municipality and $80 \mathrm{~km}$ from Craiova municipality and with access to the county road 661 (Figure 4). 


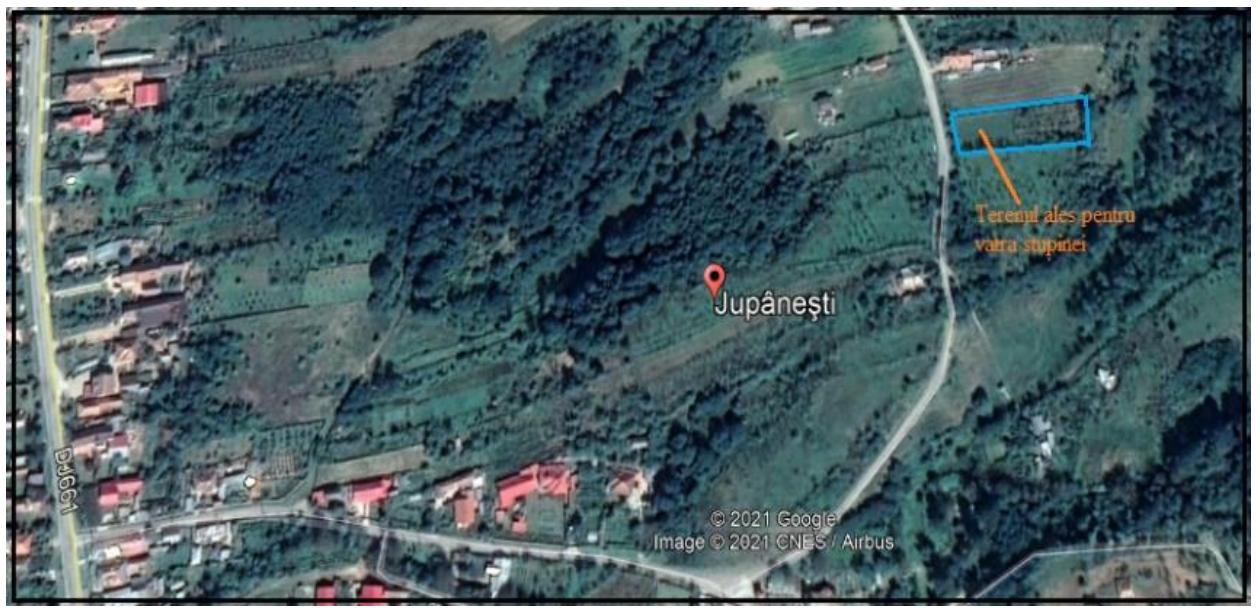

Figure 4. The location of the land where the survey for the establishment of the apiary was carried out

For the design of an apiary with vertical beehives, taking into account the provisions of the beekeeping Law No 383/2013, according to which a minimum space of $5 \mathrm{~m}^{2}$ must be provided for each bee family, the beehives will be placed in two lines on the land area of $2000 \mathrm{~m}^{2}$, with 50 vertical beehives with shed, therefore a total of 100 beehives. The area occupied by vertical beehives is $S_{\text {beehives }}=100 \times 5$ $=500 \mathrm{~m}^{2}$ (Figure 5).

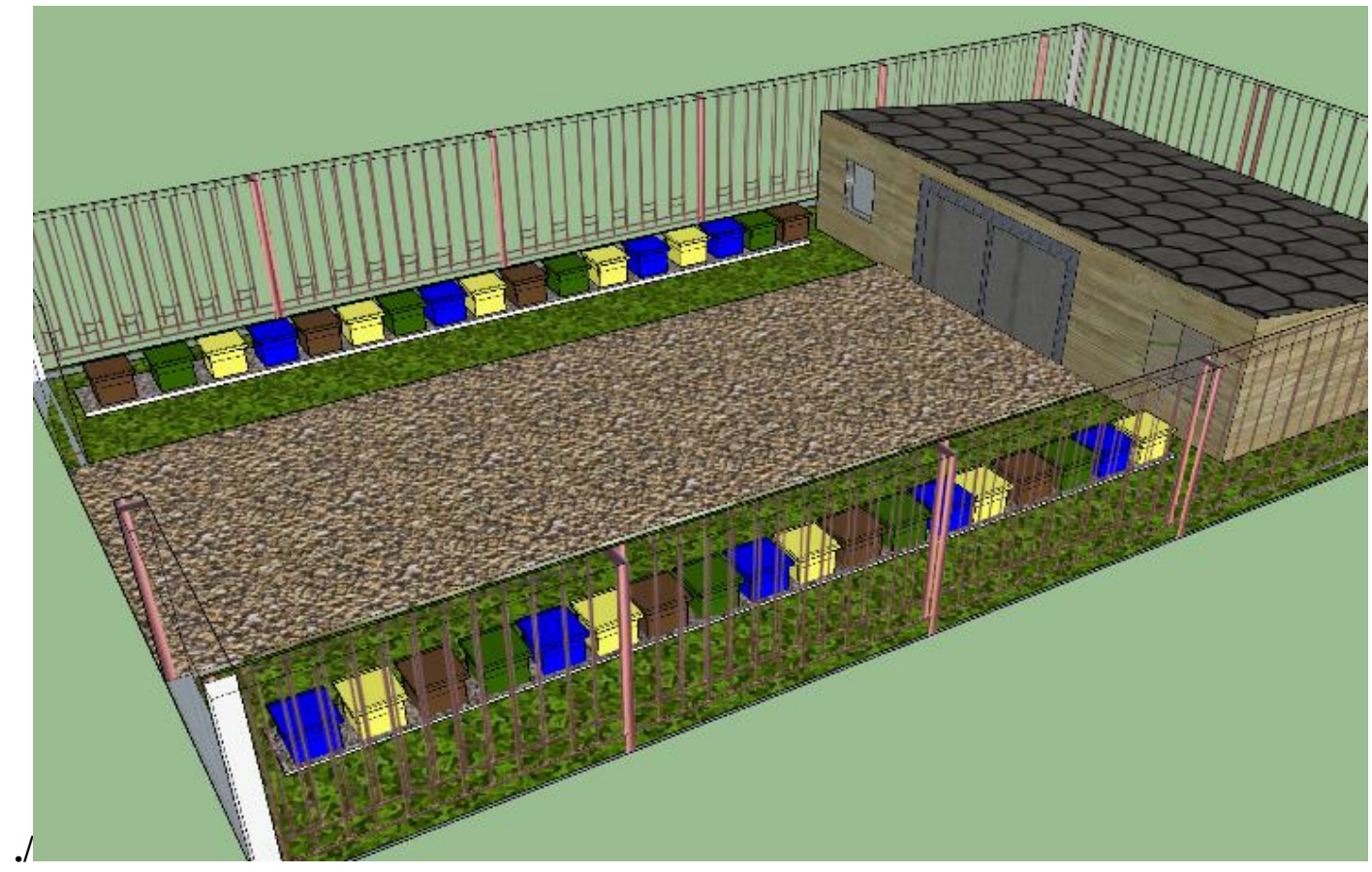

Figure 5. The apiary farm design scheme

Between the two lines, a ballast access path is arranged (for the beehives transport vehicles) and a behind each row of beehives it sows grass for heavy traffic. The transport of beehives in the harvesting areas is carried out by means of a van (with a carrying capacity of 40 vertical beehives) and a two-axle trailer (with a carrying capacity of 60 vertical beehives with shed) (Figure 6). 

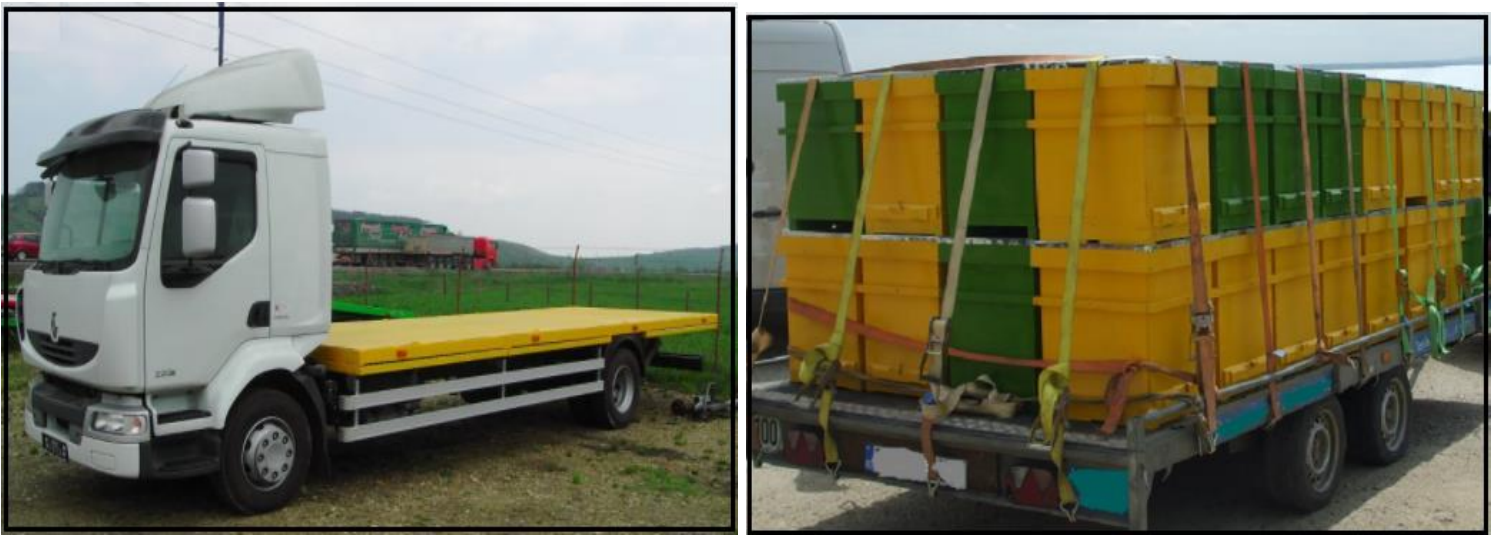

Figure 6. Van and double-axle trailer for the transportation of vertical beehives

In the northern part of the land, is being arranged a beekeeping warehouse (with a usable area of 50 $\mathrm{m}^{2}$, in which the beekeeping inventory of the apiary is stored). The beekeeping inventory consists of the following equipment used in the harvesting and valorisation of the bee products: centrifuge (electric, automatic, with 4 frames), pollen collector, propolis collector, wax smelter (solarium), uncapping tray, bee smoker, uncapping fork and knife and bee suit (Figure 7).

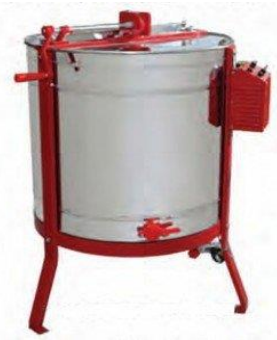

Centrifuge

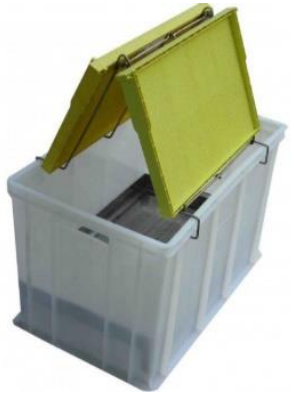

Uncapping tray

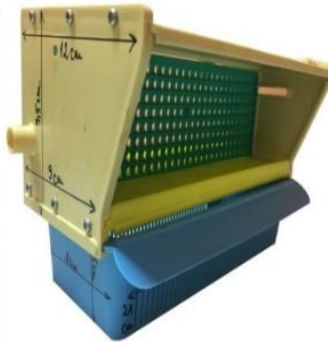

Pollen collector

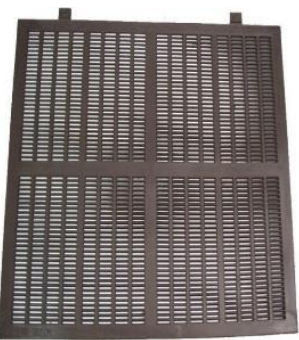

Propolis collector

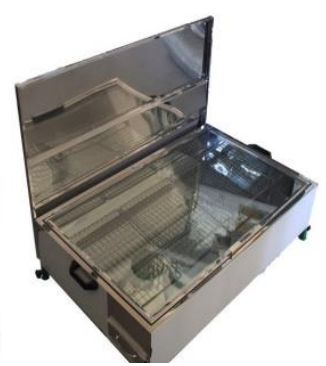

Wax smelter

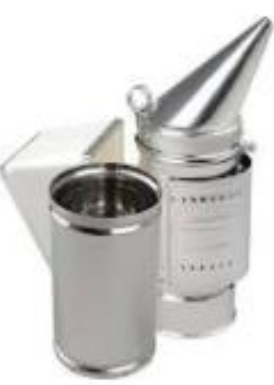

Bee smoker

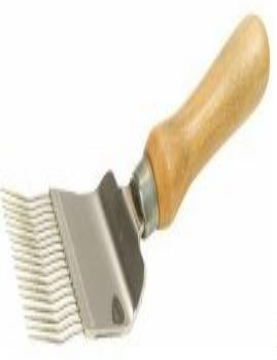

Uncapping fork and knife

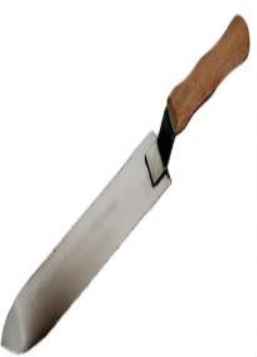

Beekeeper suit

Figure 7. Beekeeping inventory consisting of the equipment used for harvesting the bee products

In order to illustrate the activities carried out and their duration on the apiary, the Gantt chart (Table 1) was made. Thus, during the first and second quarter of the first year of the investment, will be carried out the activities of: concluding the land donation contract, installation of the cars access platform, 
construction of the beekeeping warehouse with laying-up supports for the vertical beehives and acquisition of the 100 vertical beehives with bee families.

During the third and fourth quarter of the first year of the investment, shall be made the arrangements for obtaining the producer certificate, the veterinary health authorization, the apiary permit and the one for the movement in harvesting. In the first quarter of the second investment year, shall be acquired the beekeeping inventory required to harvest of apiculture products and for the maintenance of bee families. In the second quarter of second investment year, will be concluded he pre-contracts for the marketing of apiculture products with the Association of Bee Breeders and with other economic operators which offer a better price for their apiculture products (honey, pollen, wax and propolis), estimated to be obtained for the four major crops (rape, acacia, silver linden and sunflower) of an apiary year.

The marketing of beekeeping products will be done en-gross, on the basis of pre-purchase contracts, and from the second investment year both beekeeping products and bee colonies will be marketed.

Three seasonal workers will be employed (for a period of 90 days) in order to fit the apiary, and starting with year 2 will be hired day workers (to carry out maintenance activities for beehives, to take part in loading and unloading beehives from the means of transportation, for uncapping and extraction of honey).

Table 1. Gantt Chart for the activities in the apiary, and their duration

\begin{tabular}{|c|c|c|c|c|c|c|c|c|c|c|c|c|c|c|c|c|}
\hline \multirow{2}{*}{$\begin{array}{l}\text { PLANNED } \\
\text { ACTIVITIES }\end{array}$} & \multicolumn{4}{|c|}{$\begin{array}{c}\text { YEAR 1 / } \\
\text { QUARTER }\end{array}$} & \multicolumn{4}{|c|}{$\begin{array}{l}\text { YEAR 2 / } \\
\text { QUARTER }\end{array}$} & \multicolumn{4}{|c|}{$\begin{array}{l}\text { YEAR 3 / } \\
\text { QUARTER }\end{array}$} & \multicolumn{4}{|c|}{$\begin{array}{c}\text { YEAR 4 / } \\
\text { QUARTER }\end{array}$} \\
\hline & I & II & III & IV & I & II & III & IV & I & II & III & IV & I & II & III & IV \\
\hline $\begin{array}{l}\text { Drawing up } \\
\text { documentation } \\
\text { on the transfer } \\
\text { of ownership of } \\
\text { the land on } \\
\text { which the } \\
\text { beehives will be } \\
\text { placed. } \\
\text { Setting up the } \\
\text { apiary }\end{array}$ & & & & & & & & & & & & & & & & \\
\hline $\begin{array}{l}\text { Purchase of } 100 \\
\text { vertical } \\
\text { beehives with } \\
100 \text { bee families }\end{array}$ & & & & & & & & & & & & & & & & \\
\hline $\begin{array}{l}\text { Acquisition of } \\
\text { the apiculture } \\
\text { inventory }\end{array}$ & & & & & & & & & & & & & & & & \\
\hline $\begin{array}{l}\text { Acquisition of } \\
\text { auto-equipment } \\
\text { and of dual axis } \\
\text { trailer }\end{array}$ & & & & & & & & & & & & & & & & \\
\hline $\begin{array}{l}\text { Purchase of } \\
\text { storage vessels } \\
\text { for apiculture } \\
\text { products }\end{array}$ & & & & & & & & & & & & & & & & \\
\hline $\begin{array}{l}\text { Preparation of } \\
\text { beehives for } \\
\text { production }\end{array}$ & & & & & & & & & & & & & & & & \\
\hline
\end{tabular}




\begin{tabular}{|c|c|c|c|c|c|c|c|c|c|c|c|c|c|c|c|c|}
\hline \multirow{2}{*}{$\begin{array}{c}\text { PLANNED } \\
\text { ACTIVITIES }\end{array}$} & \multicolumn{4}{|c|}{$\begin{array}{c}\text { YEAR 1 / } \\
\text { QUARTER }\end{array}$} & \multicolumn{4}{|c|}{$\begin{array}{c}\text { YEAR 2 / } \\
\text { QUARTER }\end{array}$} & \multicolumn{4}{|c|}{$\begin{array}{c}\text { YEAR 3 / } \\
\text { QUARTER }\end{array}$} & \multicolumn{4}{|c|}{$\begin{array}{c}\text { YEAR 4 / } \\
\text { QUARTER }\end{array}$} \\
\hline & I & II & III & IV & I & II & III & IV & I & II & III & IV & I & II & III & IV \\
\hline $\begin{array}{l}\text { Movement for } \\
\text { harvesting in } \\
\text { rape }\end{array}$ & & & & & & & & & & & & & & & & \\
\hline $\begin{array}{l}\text { Movement for } \\
\text { harvesting in } \\
\text { acacia }\end{array}$ & & & & & & & & & & & & & & & & \\
\hline $\begin{array}{l}\text { Movement for } \\
\text { harvesting in } \\
\text { tilia }\end{array}$ & & & & & & & & & & & & & & & & \\
\hline $\begin{array}{l}\text { Movement for } \\
\text { harvesting in } \\
\text { sunflower }\end{array}$ & & & & & & & & & & & & & & & & \\
\hline $\begin{array}{l}\text { Preparation of } \\
\text { beehives for } \\
\text { winter }\end{array}$ & & & & & & & & & & & & & & & & \\
\hline
\end{tabular}

\section{Results and discussions}

The setting up of a beekeeping farm with 100 vertical beehives in the rural area of Gorj County with a view to harvesting and marketing the apiculture products (honey, wax, propolis, and pollen) is reflected in the economic analysis of the investment:

\subsection{Calculation of the value of the investment}

Is based on the fact that the establishment of a beekeeping or apiary farm with 100 bee families involves the allocation of the following categories of expenditure (Table 2):

- elaboration of cadastre documents, and all the land documents for the area on which the apiary will be built

- land use workings (levelling with bulldozer)

- implementation of driveways (for the beehives transport vehicles)

- building the apiculture storage

- construction of the supports on which the beehives will be placed

- acquisition of beehives and bee families

- acquisition of beekeeping inventory

- purchase of fuel necessary for the transport of beehives into harvesting

- acquisition of auto-equipment and dual axis trailer

- preventive treatments administered to bees

- seasonal staff

Table 2. Calculation of the total investment for setting up a beekeeping apiary with 100 beehives

\begin{tabular}{|l|l|}
\hline \multicolumn{1}{|c|}{ Category of expenditure } & \multicolumn{1}{c|}{ Value (lei) } \\
\hline $\begin{array}{l}\text { elaboration of the cadastre, and all of the land } \\
\text { documents for the area on which the apiary will be } \\
\text { built }\end{array}$ & 1.500 \\
\hline land use workings (levelling with bulldozer) & $4 \mathrm{~h} \times 250$ lei $/ \mathrm{h}=1.000$ \\
\hline implementation of driveways & $50 \mathrm{~m}^{3}$ railroad bed $\times 65 \mathrm{lei} / \mathrm{m}^{3}=3.250$ \\
\hline
\end{tabular}




\begin{tabular}{|c|c|}
\hline Category of expenditure & Value (lei) \\
\hline & $\begin{array}{l}\text { levelling and compaction } 5 \mathrm{~h} \times 250 \mathrm{lei} / \mathrm{h}= \\
1.250\end{array}$ \\
\hline $\begin{array}{l}\text { Building the store: timbers; chains; boards; } \\
\text { bituminous shingles; PVC windows and doors with } \\
\text { double-glazed glass; labour }\end{array}$ & 5.000 \\
\hline $\begin{array}{l}\text { Construction of the supports on which the beehives } \\
\text { will be placed }\end{array}$ & $100 \times 30$ lei/support $=3.000$ \\
\hline Acquisition of beehives and bee families & $\begin{array}{l}100 \times 500 \text { lei (beehive }+ \text { bee family) }= \\
50.000\end{array}$ \\
\hline $\begin{array}{l}\text { Acquisition of the apiculture inventory: } \\
-\quad 4 \text { protective apiculture beekeeper suits } \\
-\quad 1 \text { automatic tangential centrifuge with } 4 \\
\text { frames } \\
-\quad 1 \text { uncapping tray } \\
-\quad 100 \text { pollen collectors from the beehive's } \\
\quad \text { entry } \\
-\quad 100 \text { propolis collectors } \\
-\quad 1 \text { solar wax melting } \\
-\quad 3 \text { uncapping knives } \\
-\quad 3 \text { uncapping forks } \\
-\quad 1 \text { frame transport trolley }\end{array}$ & $\begin{array}{l}4 \times 70=280 \\
1 \times 2000=2.000 \\
1 \times 270=270 \\
100 \times 38=3.800 \\
100 \times 22=2.200 \\
1 \times 1200=1.200 \\
3 \times 70=210 \\
3 \times 12=36 \\
1 \times 300=300\end{array}$ \\
\hline $\begin{array}{l}\text { Purchase of treatments (Varaket, Mavriol) and } \\
\text { fumigator }\end{array}$ & $\begin{array}{l}3 \times 50=150 \\
1 \times 50=50\end{array}$ \\
\hline Fuel costs for transportation in harvest & 500 motorină/an x 5 lei/l $=2.500$ \\
\hline $\begin{array}{l}\text { Acquisition of auto-equipment and } \\
\text { of dual-axis trailer }\end{array}$ & $\begin{array}{l}1 \times 50.000 \\
1 \times 10.000\end{array}$ \\
\hline Staff expenditure & 3.000 lei/year \\
\hline TOTAL & 140.996 lei \\
\hline
\end{tabular}

3.2. Calculation of estimated revenues from the marketing of apiculture products and bee swarms for the first 4 years of production (Table 3 )

Table 3. Calculation of the estimated income during the first 4 years following the establishment of the apiary

\begin{tabular}{|c|c|}
\hline Calculation items by product & Value (lei) \\
\hline $\begin{array}{l}\text { A. Direct expenditure } \\
\text { - } \\
\text { - } \\
\text { acquischase of } 100 \text { beehives } \\
\text { - } \\
\text { acquisition of auto-equipment and of dual-axis trailer } \\
\text { construction of beekeeping story and arrangement of the apiary } \\
\text { (land registration and transfer of ownership, land levelling, } \\
\text { fences, access routes, support props for beehives) } \\
\text { Purchase of treatments (Varaket, Mavriol) and fumigator } \\
\text { B. Salaries } \\
\text { C. Fuel costs for transportation in harvest }\end{array}$ & $\begin{array}{c}50.000 \\
60.000 \\
10.300 \\
15.000 \\
\\
200 \\
3000 \times 4 \text { years }=12.000 \\
1000 \times 4 \text { years }=4.000 \\
\mathbf{1 5 1 . 5 0 0}\end{array}$ \\
\hline
\end{tabular}




\begin{tabular}{|c|c|}
\hline Calculation items by product & Value (lei) \\
\hline $\begin{array}{l}\text { Selling expenses } \\
-\quad 200 \mathrm{~L}(10 \text { pieces }) \text { metal barrels } \\
-\quad \text { Domestic bags for wax and vacuum bags for pollen }\end{array}$ & $\begin{array}{l}2500 \\
200\end{array}$ \\
\hline TOTAL & 2700 \\
\hline TOTAL COST & 154.200 \\
\hline $\begin{array}{l}\text { Income calculated in the first } 4 \text { years following the establishment of the } \\
\text { apiary: }\end{array}$ & \\
\hline $\begin{array}{l}\text { - } \quad \text { rape honey }(5 \mathrm{~kg} / \text { beehive } \times 100) \times 4 \text { years }=2000 \mathrm{~kg} \times 13 \text { lei } / \mathrm{kg} \\
\text { - } \\
\text { acacia honey }(10 \mathrm{~kg} / \text { beehive } \times 100) \times 4 \text { years }=4000 \mathrm{~kg} \times 25 \\
\text { lei } / \mathrm{kg}\end{array}$ & $\begin{array}{c}26.000 \\
100.000\end{array}$ \\
\hline - tilia honey $(10 \mathrm{~kg} /$ beehive $\times 100) \times 4$ years $=4000 \mathrm{~kg} \times 16$ lei $/ \mathrm{kg}$ & 64.000 \\
\hline $\begin{array}{l}\text { - } \quad \text { sunflower honey }(10 \mathrm{~kg} / \text { beehive } \times 100) \times 4 \text { years }=4000 \mathrm{~kg} \times 13 \\
\text { lei } / \mathrm{kg}\end{array}$ & 52.000 \\
\hline - pollen $[(5 \mathrm{~kg} /$ year $/$ beehive $\times 100) \times 4$ years $]=2000 \times$ lei $35 / \mathrm{kg}$ & 70.000 \\
\hline - $\quad$ propolis $(10 \mathrm{~kg} /$ year/apiary x 4 years $)=40$ x 100 lei $/ \mathrm{kg}$ & 4.000 \\
\hline - $\quad$ beeswax $(3 \mathrm{~kg} /$ beehive $\mathrm{x} 100 \times 4$ years $)=1200 \mathrm{~kg}$ x 20 lei $/ \mathrm{kg}$ & 24.000 \\
\hline - bee swarms $(50$ colony/year $\times 4$ years $)=200 \times 350$ lei $/$ swarm & 70.000 \\
\hline ESTIMATED TOTAL REVENUE FOR THE FIRST 4 YEARS & 410.000 \\
\hline $\begin{array}{l}\text { Gross profit } \\
410.000 \text { (revenues in the first } 4 \text { years after setting up) - } 154.200 \text { (start-up } \\
\text { costs) }\end{array}$ & 255.800 \\
\hline $\begin{array}{l}\text { Net profit } \\
\text { Net profit }=[\text { (gross profit }- \text { expenses })-10 \% \text { tax on income from } \\
\text { agricultural activities }]\end{array}$ & 230.220 \\
\hline
\end{tabular}

\subsection{Investment depreciation}

The investment in beekeeping is profitable if at least 4 crops are provided per year and if the weather is favourable: temperatures above $20^{\circ} \mathrm{C}$ and no precipitation over a period of more than 3 days/harvest). Total gross income for the first year of production $=102.500$ lei

Total net income with tax deduction of $10 \%=92.250$ lei

The revenue obtained in production year 1 shall come from the sale of the following apiculture products:

- rapeseed honey $=6.500$ lei

- acacia honey $=25.000$ lei

- tilia honey $=16.000$ lei

- sunflower honey $=13.000$ lei

- pollen = lei 17.500

- propolis $=$ lei 1.000

- beeswax $=6.000$ lei

- swarm of bees $=17.500$

Total gross income for the first year of production $=$ lei 102.500

Total net income with tax retention of $10 \%=$ lei 92.250

\section{Conclusions}

The establishment of a beekeeping farm (apiary) in a rural area in Gorj County for 100 vertical beehives with shed can be a business idea that contributes to the rural development and to the diversification of entrepreneur's income. 
The law governing bee breeding and pastoral activities is the Law on beekeeping No 383/2013. Designation, description, definition, characteristics and composition of honey are mentioned in the methodological norms approved by Order of the Minister of Agriculture No 1356/2014.

The cost of the investment necessary to implement a beekeeping farm with a number of 100 vertical beehives and the fitting of a apiary with an area of $2.000 \mathrm{~m}^{2}$ is of $141.000,00 \mathrm{lei}$, and the net income calculated for the first 4 years of production is of about 230.220 lei.

The investment expenses are 154.200 lei and the net income in the first year of production is of 92.250 lei, so that under favourable weather conditions achieving 4 harvests per year, the depreciation of the investment costs and profit is made from the second year of production.

\section{References}

[1] Romanian Association of Bee Breeders (2018), Guide of good practices in beekeeping, Publishing of the Association of Romanian Bee Breeders, Bucharest

[2] Romanian Association of Bee Breeders (2002), The beekeeper's manual - VIIth Edition, Publishing of the Association of Romanian Bee Breeders, Bucharest

[3] Marghitaș L., Al., (2005), Bees and their products, Publishing House Ceres, București

[4] Order no 1356/2014 on approving of the technical rules on bees'honney

[5] www.apicris.ro

[6] www.apiflora.ro

[7] www.cgtrader.com

[8] www.stuparul.ro 